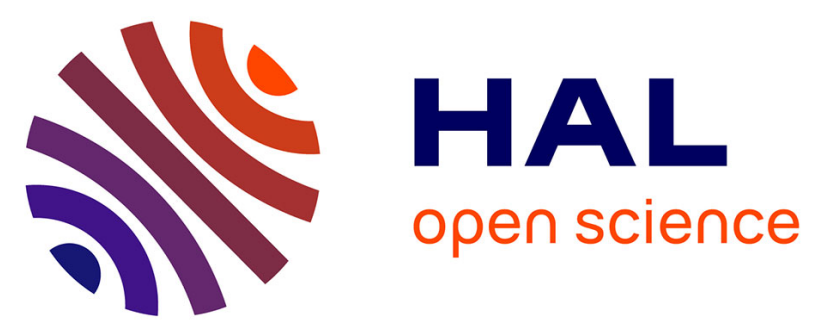

\title{
An extremely radioresistant green eukaryote for radionuclide bio-decontamination in the nuclear industry
}

Corinne Rivasseau, Emmanuel Farhi, Ariane Atteia, Alain Couté, Marina

Gromova, Diane de Gouvion Saint Cyr, Anne-Marie Boisson, Anne-Sophie

Féret, Estelle Compagnon, Richard Bligny

\section{To cite this version:}

Corinne Rivasseau, Emmanuel Farhi, Ariane Atteia, Alain Couté, Marina Gromova, et al.. An extremely radioresistant green eukaryote for radionuclide bio-decontamination in the nuclear industry. Energy \& Environmental Science, 2013, 6 (4), pp.1230 - 1239. 10.1039/c2ee23129h . hal-00796855

\section{HAL Id: hal-00796855 \\ https://hal.science/hal-00796855}

Submitted on 27 Jun 2013

HAL is a multi-disciplinary open access archive for the deposit and dissemination of scientific research documents, whether they are published or not. The documents may come from teaching and research institutions in France or abroad, or from public or private research centers.
L'archive ouverte pluridisciplinaire HAL, est destinée au dépôt et à la diffusion de documents scientifiques de niveau recherche, publiés ou non, émanant des établissements d'enseignement et de recherche français ou étrangers, des laboratoires publics ou privés. 
Cite this: Energy Environ. Sci., 2013, 6, 1230

Received 9th August 2012

Accepted 21st December 2012

DOI: $10.1039 / \mathrm{c} 2 \mathrm{ee} 23129 \mathrm{~h}$

www.rsc.org/ees

\section{An extremely radioresistant green eukaryote for radionuclide bio-decontamination in the nuclear industry}

\author{
Corinne Rivasseau, ${ }^{\text {*abcd }}$ Emmanuel Farhi, ${ }^{\text {ee }}$ Ariane Atteia, ${ }^{f}$ Alain Couté, ${ }^{g}$ \\ Marina Gromova, ${ }^{\text {' }}$ Diane de Gouvion Saint Cyr, ${ }^{\text {abcde }}$ Anne-Marie Boisson, ${ }^{\text {abcd }}$ \\ Anne-Sophie Féret, ${ }^{\text {abcd }}$ Estelle Compagnon ${ }^{\mathrm{e}}$ and Richard Bligny ${ }^{\text {abcd }}$
}

\begin{abstract}
Nuclear activities generate radioactive elements which require processes for their decontamination. Although biological remediation has proved to be efficient in industrial applications, no biotechnology solution is currently operational for highly radioactive media. Such a solution requires organisms that accumulate radionuclides while withstanding radioactivity. This paper describes the potentialities of an extremophile autotrophic eukaryote, Coccomyxa actinabiotis nov. sp., that we isolated from a nuclear facility and which withstands huge ionizing radiation doses, up to 20000 Gy. Half the population survives $10000 \mathrm{~Gy}$, which is comparable to the hyper-radioresistant well-known prokaryote Deinococcus radiodurans. The cell metabolic profile investigated by nuclear magnetic resonance was hardly affected by radiation doses of up to $10000 \mathrm{~Gy}$. Cellular functioning completely recovered within a few days. This outstanding microalga also strongly accumulates radionuclides, including ${ }^{238} \mathrm{U},{ }^{137} \mathrm{Cs},{ }^{110 \mathrm{~m}} \mathrm{Ag},{ }^{60} \mathrm{Co}$, ${ }^{54} \mathrm{Mn},{ }^{65} \mathrm{Zn}$, and ${ }^{14} \mathrm{C}$ (decontamination above $85 \%$ in $24 \mathrm{~h}$, concentration factor, $1000-450000 \mathrm{~mL} \mathrm{~g}^{-1}$ fresh weight). In $1 \mathrm{~h}$, the microalga revealed as effective as the conventional physico-chemical ionexchangers to purify nuclear effluents. Using this organism, an efficient real-scale radionuclide biodecontamination process was performed in a nuclear fuel storage pool with an important reduction of waste volume compared to the usual physico-chemical process. The feasibility of new decontamination solutions for the nuclear industry and for environmental clean-up operations is demonstrated.
\end{abstract}

\section{Broader context}

The nuclear industry generates radioactive toxics and requires processes for their decontamination inside the facilities themselves and of the effluents released into the environment. Radionuclide decontamination is currently performed using physico-chemical methods. Despite their robustness and efficiency, these methods are expensive, do not remove completely certain elements, especially ${ }^{14} \mathrm{C}$, one of the main radionuclides released in effluents, and generate large volumes of secondary wastes when applied to environmental contaminations. Biological methods have proved to be efficient and competitive in various industrial applications. However, no viable method is presently available for the bio-decontamination of highly radioactive media. Such a method would require organisms that simultaneously accumulate radionuclides while withstanding their chemical and radiological toxicity and the radioactivity of the environment. Here we report on a new autotrophic green microalga, isolated from a radioactive nuclear site, which is extremely radioresistant and strongly accumulates radionuclides, including ${ }^{14} \mathrm{C}$. It was used in a real-scale bio-decontamination process with considerable reduction of radioactive waste volume. This microalga provides an excellent opportunity for new decontamination technologies. It could be used in bio-processes in the nuclear industry where its performance would complement those of the conventional methods and in the environmental field for the clean-up of accidentally contaminated water where large volumes have to be processed. The characterisation of an autotrophic eukaryote with such properties may also have an important outcome for the fundamental biology of adaptation to extreme environments.

\footnotetext{
${ }^{a}$ CEA, IRTSV, Laboratoire de Physiologie Cellulaire Végétale, F-38054 Grenoble, France ${ }^{b}$ CNRS, UMR5168, F-38054 Grenoble, France

${ }^{c}$ Université de Grenoble, F-38000 Grenoble, France

${ }^{d} I N R A$, F-38054 Grenoble, France. E-mail: corinne.rivasseau@cea.fr

${ }^{e}$ Institut Laue-Langevin, F-38009 Grenoble, France. E-mail: farhi@ill.eu; estelle. compagnon@gmail.com

${ }^{f}$ Unité de Bioénergétique et Ingénierie des Protéines-UMR 7281, CNRS-Aix-Marseille Univ, F-13402 Marseille, France

${ }^{g}$ Muséum National d'Histoire Naturelle, UMR7245, F-75005 Paris, France

${ }^{h} C E A$, INAC, SCIB, Laboratoire de Résonance Magnétique, F-38054 Grenoble, France
}

\section{Introduction}

Nuclear energy technologies generate radioactive and chemically toxic compounds during the whole nuclear fuel cycle, from mining to reprocessing or waste treatment plants. These technologies require processes for radionuclide decontamination inside the facilities themselves and of the effluents which will be released into the environment. In the event of a nuclear disaster, such as in Chernobyl or Fukushima, massive quantities of 
radionuclides are released into the environment and contaminate water and soil for decades. ${ }^{1,2}$ In the Fukushima-Daiichi reactors themselves, radioactivity reached $3.8 \mathrm{GBq} \mathrm{L}^{-1}$ in stagnant water on the basement floor of the Unit 1 turbine building; ${ }^{3}$

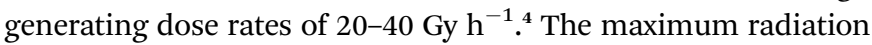
dose for human survival is $10 \mathrm{~Gy},{ }^{5}$ rendering the treatment of the contaminated water complicated.

At nuclear power plants, treatment methods for radionuclide removal from liquid streams include evaporation, chemical precipitation/flocculation, solid/liquid separation, reverse osmosis or ultrafiltration, sorption, and ion exchange. ${ }^{6,7}$ Ion exchange is one of the most common and effective methods employed. ${ }^{8}$ Some drawbacks include high cost, incomplete removal of certain ions ${ }^{9}$ and problematic disposal of spent ionexchangers which requires special approaches and precautions. $^{8}$ The treatment of radionuclide contamination in the environment relies on the same physico-chemical techniques which are generally costly and environmentally destructive, require much reagent and energy, and generate secondary toxic sludge or waste products. ${ }^{9,10}$

Decontamination by living organisms or extracts from organisms may constitute an alternative or a complement to the physico-chemical processes traditionally used for radionuclide purification. ${ }^{9,10}$ Such an alternative may be particularly interesting for environmental applications where huge volumes of water or soil have to be processed. In various applications, biological remediation has proved to be competitive against conventional methods. Bioremediation generally offers a wider field of application, a lower consumption of energy and chemicals, and lower cost and impact on the environment. ${ }^{11,12}$ Living organisms combine physico-chemical contaminant fixation by biosorption with metabolism-dependent uptake and accumulation. In a nuclear environment, for maximum decontamination performance, organisms must be capable of strongly accumulating radionuclides, while withstanding their toxicity and must at the same time be highly radioresistant. To our knowledge, no bio-process currently exists for the decontamination of highly radioactive water.

Among radiation-resistant species stand the cyanobacterium Chroococcidiopsis sp., ${ }^{13}$ the archaea Pyrococcus furiosus ${ }^{14}$ and Halobacterium sp., ${ }^{15}$ the amoeba Dictyostelium discoideum, ${ }^{16}$ and the fungus Alternaria alternata ${ }^{17}$ which withstand ionizing radiation doses of 2500 to $5000 \mathrm{~Gy}$. The most radiation-resistant organisms described so far are prokaryotes ${ }^{18}$ which include the bacterium Deinococcus radiodurans which grows under an ionizing radiation dose rate of $50 \mathrm{~Gy} \mathrm{~h}^{-1}$ and survives doses of up to $20000 \mathrm{~Gy} .{ }^{19,20}$ However, using $D$. radiodurans for the in situ bioremediation of nuclear waste sites would require genetic engineering for the bacterium to acquire resistance to toxic metals and remediating capabilities. ${ }^{21}$ Moreover, its culture requires a supply of carbon nutrients and is therefore sensitive to contamination by other bacteria.

Conversely, plants and algae fix a wide range of contaminants, including toxic metals and radionuclides. ${ }^{11,12,22}$ Photosynthetic organisms have the advantages of requiring less energy and mineral culture media which are less sensitive to bacterial contamination. Microalgae possess, in addition, a large cell wall surface, which is interesting for decontamination by both biosorption and metabolism-dependent mechanisms. However, the $50 \%$ lethal dose $\left(\mathrm{LD}_{50}\right)$ of ionizing radiation for algae generally falls in the $30-1200$ Gy range. ${ }^{23}$ In 2008 , a microalga of the Chlorophyceae class which tolerated ionizing radiation with an $\mathrm{LD}_{50}$ of 6000 Gy was described but radioactive isotope accumulation had not been assessed.$^{24} \mathrm{~A}$ microalga of the Desmidiales order, Closterium moniliferum, was recently considered for strontium decontamination but radioactive isotope accumulation and resistance to radioactivity have not been evaluated..$^{25,26}$

This work characterizes the properties and the potential use of a new microalga discovered in a high ionizing radiation nuclear environment in remediation technologies. This alga was isolated from a pool used to store spent fuel elements in a nuclear reactor. The new species, identified at the morphological, biochemical and genomic level, belongs to the Coccomyxa genus and was named Coccomyxa actinabiotis, from the characteristics of the place it lives in. Its radioresistance evaluated using physiological and metabolic analyses is outstanding for a eukaryote. Its ability to fix radionuclides and toxic metals has also been examined. This microalga combines both properties of extreme radioresistance and radionuclide accumulation, being able to fix radionuclide via metabolically inactive and active processes even in a highly radioactive environment, which is particularly interesting for ${ }^{14} \mathrm{C}$ decontamination. It is therefore an excellent candidate for new remediation solutions in a highly radioactive environment. Its use for the bio-decontamination of radionuclides on a real-scale was validated in the storage pool of a nuclear facility.

\section{Materials and methods}

\section{Algae culture and identification}

Algae were grown at $21{ }^{\circ} \mathrm{C}$ in different culture media in $800 \mathrm{~mL}$ flasks aerated on an orbital shaker (Innova 2300, New Brunswick Scientific, Enfield, CT) at $100 \mathrm{rpm}$, under a continuous illumination of $70 \mu \mathrm{mol}$ photon $\mathrm{m}^{-2} \mathrm{~s}^{-1}$. C. actinabiotis was grown in a modified Bold Basal Medium (BBM) (Sigma-Aldrich, Saint-Louis, MO) diluted twice with Milli-Q water (Millipore, Molsheim, France), C. reinhardtii in TAP medium (Gibco, Life Technologies SAS, Saint Aubin, France), and C. chodatii in BBM.

Scanning electron microscopy was performed on cryo-dessicated cells using a LEO 1530 scanning electron microscope (Zeiss, Oberkochen, Germany) operating at a voltage of $20 \mathrm{kV}$ EHT. For genomic identification, the sequence of the $C$. actinabiotis nuclear genome region spanning the genes for $18 \mathrm{~S}$ ribosomal RNA-Internal Transcribed Spacer (ITS) 1-5.8S rRNAITS2-28S rRNA (500 first bases) was amplified by PCR (4065 bp) using primers EAF3 (5'-tcgacaatetggttgatcetgecag-3') and ITS055R ( $5^{\prime}$-ctccttggtccgtgtttcaagacggg- $\left.3^{\prime}\right)$. For the phylogenetic analysis, the same genome region was sequenced in $C$. chodatii strain SAG 216-2 and C. peltigerae strain SAG 216-5. Sequences of the nuclear genome region spanning the genes for $18 \mathrm{~S}$ ribosomal RNA-ITS1-5.8S rRNA-ITS2-28S rRNA (500 first bases) used are deposited in the EMBL/GenBank databases under 
accession numbers FR850476 (C. actinabiotis strain CCAP 216-25), FN597598 (C. chodatii strain SAG 216-2) and FN597599 (C. peltigerae strain SAG 216-5).

\section{Radioresistance}

To assess the resistance of algae to ionizing radiation (Fig. 2 and $3)$, C. actinabiotis cells initially grown in BBM $\left(10^{7}\right.$ cells per $\left.\mathrm{mL}\right)$ were concentrated to $1-2 \times 10^{9}$ cells per $\mathrm{mL}$ and inserted inside a used nuclear fuel element (UNFE) providing a $\gamma$-radiation flux of $4000 \mathrm{~Gy} \mathrm{~h}^{-1}$. Irradiated algae were allowed to recover in fresh BBM. The cell mortality and the growth were measured after acute irradiation using a neutral red staining method ${ }^{27}$ and using a Malassez counting cell and compared to the control, as described in Farhi et $a .^{24}$ The neutral red concentration was $0.003-0.03 \% \mathrm{w} / \mathrm{v}^{27,28}$ Cell observation was performed $30 \mathrm{~min}$ to $1 \mathrm{~h}$ after dye application using an Optiphot microscope (Nikon, Japan) with a magnification of $1000 \times$. C. actinabiotis mortality was maximum 3 days after irradiation. As high survival rates were obtained for C. actinabiotis (85\% mortality i.e. 15\% survival at $20000 \mathrm{~Gy}$, the highest radiation dose tested), the response was plotted on a linear scale. The same protocol was used for C. chodatii and $C$. reinhardtii.

Changes in the algae metabolic profile after acute irradiation (Fig. 4 and 5) were analyzed using ${ }^{1} \mathrm{H}$ nuclear magnetic resonance (NMR). Prior to NMR analysis, cellular metabolites were extracted using a methanol-chloroform mixture. ${ }^{29}$ The cells $(0.3-0.7 \mathrm{~g}$ fresh weight $(\mathrm{FW}))$ were ground in a mortar in liquid nitrogen in the presence of maleate $\left(0.5 \mu \mathrm{mol} \mathrm{g}{ }^{-1} \mathrm{FW}\right)$ and $1 \mathrm{~mL}$ of $\mathrm{H}_{2} \mathrm{O}$ and transferred into a nitrogen-cooled vial. After adding $1.5 \mathrm{~mL}$ of chloroform and $4.5 \mathrm{~mL}$ of methanol, the mixture was vortexed and incubated for $15 \mathrm{~min}$ at room temperature. Following the addition of $1 \mathrm{~mL}$ of chloroform and $1 \mathrm{~mL}$ of $\mathrm{H}_{2} \mathrm{O}$, the mixture was vortexed and centrifuged at $10000 \mathrm{~g}$ at $4{ }^{\circ} \mathrm{C}$ for $10 \mathrm{~min}$. The polar phase was recovered, evaporated and freeze dried. The dried extract was dissolved in $0.6 \mathrm{~mL}$ of $\mathrm{D}_{2} \mathrm{O}$ containing $100 \mathrm{mM}$ potassium phosphate buffer at $\mathrm{pH}$ 7.0, $4 \mathrm{mM} \mathrm{NaN}$, (trimethylsilyl)propionate-2,2,3,3- $\mathrm{D}_{4}$ (TSP), and $4 \mathrm{mM}$ ethylenediaminetetraacetic acid. The $\mathrm{pH}$ was adjusted to 7.0 with KOD or DCl. The resulting solution was lyophilized again and dissolved in $0.6 \mathrm{~mL}$ of $\mathrm{D}_{2} \mathrm{O}$. NMR analysis was performed in a $5 \mathrm{~mm}$ o.d. glass tube, at $25^{\circ} \mathrm{C}$, using a Bruker Avance 500 spectrometer (Bruker Biospin, Wissembourg, France) equipped with a $5 \mathrm{~mm}$ BBI probe. Relaxed spectra were obtained from a sum of 64-128 FIDs, recorded with a resolution of $0.084 \mathrm{~Hz}$ per pt and a $30 \mathrm{~s}$ repetition period. Fast acquisition conditions were also used to increase the signal-to-noise ratio for low concentration compounds. In that case, 256 FIDs recorded with a $60^{\circ} \mathrm{RF}$ pulse angle, a resolution of $0.17 \mathrm{~Hz}$ per pt and a $4 \mathrm{~s}$ repetition period were added. ${ }^{1} \mathrm{H}$ NMR spectra, referenced to the internal TSP chemical shift, were assigned using 1D and 2D NMR. Absolute metabolite quantity was determined from the integration of the resonance line of relaxed spectra after baseline correction. The line integrals were corrected for saturation effects when fast acquisition was used. For a complex multiplet partially superimposed to another resonance, the integration was done on the resolved part of the multiplet only. Intensity of the multiplet was measured on the spectra of the pure compound.

\section{Radionuclide decontamination}

To determine the bio-decontamination rate of $\gamma$ - and $\beta$-emitter radionuclides (Table 1), C. actinabiotis cells (250 $\mathrm{mg}$ fresh weight (FW)), initially grown in BBM, were washed three times with Milli-Q water and suspended in the light in $100 \mathrm{~mL}$ of $\mathrm{pH}$ 5.5 nuclear facility effluents initially containing different radionuclides. Effluent 1 contained the $\gamma$-emitters ${ }^{60} \mathrm{Co}(280 \pm 8$ $\left.\mathrm{Bq} \mathrm{L}^{-1}\right),{ }^{58} \mathrm{Co}\left(530 \pm 10 \mathrm{~Bq} \mathrm{~L}^{-1}\right),{ }^{110 \mathrm{~m}} \mathrm{Ag}\left(66 \pm 7 \mathrm{~Bq} \mathrm{~L}^{-1}\right),{ }^{124} \mathrm{Sb}$ $\left(1460 \pm 13 \mathrm{~Bq} \mathrm{~L}^{-1}\right),{ }^{51} \mathrm{Cr}\left(1180 \pm 12 \mathrm{~Bq} \mathrm{~L}^{-1}\right),{ }^{65} \mathrm{Zn}(120 \pm 7 \mathrm{~Bq}$ $\left.\mathrm{L}^{-1}\right)$, and ${ }^{54} \mathrm{Mn}\left(230 \pm 8 \mathrm{~Bq} \mathrm{~L}^{-1}\right)$ and the $\beta$-emitters ${ }^{3} \mathrm{H}(260000$ $\left.\mathrm{Bq} \mathrm{L}{ }^{-1}\right)$ and ${ }^{14} \mathrm{C}\left(10000 \mathrm{~Bq} \mathrm{~L}^{-1}\right)$. Effluent 2 contained the $\gamma$ emitters ${ }^{137} \mathrm{Cs}\left(67 \pm 7 \mathrm{~Bq} \mathrm{~L}^{-1}\right)$ and ${ }^{238} \mathrm{U}\left(21 \pm 3 \mathrm{~Bq} \mathrm{~L}^{-1}\right)$ and the $\beta$-emitters ${ }^{3} \mathrm{H}\left(200000 \mathrm{~Bq} \mathrm{~L}^{-1}\right)$ and ${ }^{14} \mathrm{C}\left(2000 \mathrm{~Bq} \mathrm{~L}^{-1}\right)$. After $24 \mathrm{~h}$, the decontamination rate, calculated as $\left(1-C_{\text {final }} / C_{\text {initial }}\right) \times 100$ where $C_{\text {final }}$ and $C_{\text {initial }}$ represent respectively the final and the initial radionuclide concentration in water, was determined for each isotope by analyzing water and algae preliminary separated by centrifugation at $2000 \mathrm{~g}$ using $\gamma$-spectroscopy (ITECH Instruments, Châteauneuf-Les-Martigues, France). The decontamination of ${ }^{14} \mathrm{C}$ was evaluated separately. Algae were exposed for 3 to $7 \mathrm{~h}$ to 2000 to $20000 \mathrm{~Bq} \mathrm{~L}^{-1} \mathrm{H}^{14} \mathrm{CO}_{3}{ }^{-}$in $100 \mathrm{~mL}$ of $\mathrm{pH}$ 6.5 demineralized water (matrix 3 ), under illumination. The amount of ${ }^{14} \mathrm{C}$ in water and algae was analyzed using liquid scintillation counting (Packard TriCarb 2900TR liquid scintillation analyzer, PerkinElmer, Waltham, MA).

Radionuclide bioconcentration factors (BCFs) (Fig. 6) were evaluated for algae directly harvested from the UNFE storage pool under illumination $\left(200 \mu \mathrm{mol} \mathrm{m} \mathrm{m}^{-2} \mathrm{~s}^{-1}\right)$. The $\mathrm{pH} 5.5$ demineralized water composition changes according to the components stored; it contained typically ${ }^{60} \mathrm{Co}\left(400 \mathrm{~Bq} \mathrm{~L}^{-1}\right)$, ${ }^{110 \mathrm{~m}} \mathrm{Ag}\left(1000 \mathrm{~Bq} \mathrm{~L}{ }^{-1}\right),{ }^{124} \mathrm{Sb}\left(1500 \mathrm{~Bq} \mathrm{~L}^{-1}\right),{ }^{51} \mathrm{Cr}\left(5000 \mathrm{~Bq} \mathrm{~L}^{-1}\right)$, ${ }^{65} \mathrm{Zn}\left(400 \mathrm{~Bq} \mathrm{~L}^{-1}\right),{ }^{54} \mathrm{Mn}\left(300 \mathrm{~Bq} \mathrm{~L}^{-1}\right),{ }^{3} \mathrm{H}\left(300000 \mathrm{~Bq} \mathrm{~L}^{-1}\right)$, and ${ }^{14} \mathrm{C}\left(20000 \mathrm{~Bq} \mathrm{~L}^{-1}\right)$. In experiments with different microalgae, radionuclide accumulation was found to proceed rapidly, equilibrium being reached within some hours or days. ${ }^{30,31}$ BCFs were calculated as the ratio of the radionuclide content in algae (in $\mathrm{Bq} \mathrm{g}^{-1} \mathrm{FW}$ ) to the radionuclide content in water (in $\mathrm{Bq} \mathrm{mL}^{-1}$ ), both concentrations being measured by $\gamma$-spectrometry. ${ }^{238} \mathrm{U}$ BCF was assessed by incubating C. actinabiotis (60 mg FW) with $10^{-5} \mathrm{~mol} \mathrm{~L}^{-1}$ uranyl nitrate for $24 \mathrm{~h}$ and measuring the ${ }^{238} \mathrm{U}$ concentration in algae and water using an inductively coupled plasma-mass spectrometer (ICP-MS) (Hewlett-Packard 4500 Series, Agilent Technologies, Santa Clara, CA).

To determine the fixation capacities of $\mathrm{Ag}$ and $\mathrm{Co}$, algae were suspended with an equivalent of, respectively, $6.7 \times 10^{-4}$ mole of $\mathrm{AgNO}_{3} \mathrm{~g}^{-1}$ algae $\mathrm{FW}$ in $\mathrm{BBM}$ diluted 10 times or in deionized water for 2 days and $10^{-3}$ mole of $\mathrm{CoCl}_{2} \mathrm{~g}^{-1}$ algae FW in BBM diluted 10 times for 6 days. Experiments were performed in diluted BBM to lower the concentration of chloride which forms a precipitate with silver. The presence of this precipitate was taken into account to assess the amount of silver fixed by the algae. After exposure, phases were 
separated by centrifugation at $2000 g$; algae were quickly washed with water, centrifuged again, and the metal concentration was assessed in algae and the liquid phase using ICP-MS.

Real-scale validation (Fig. 7) was performed in a nuclear facility storage pool as follows. Under normal conditions, the pool contains algae colonies, glued onto metallic parts, and which concentration in suspension is controlled by intermittent normal circulation and filtering of water which is operated regularly. The algae naturally grow in purified water from the dissolved $\mathrm{CO}_{2}$ and ambient light. Water purification by resins is operated when necessary to maintain the radionuclide concentration below the regulatory level. On day 14, two nuclear mechanical components releasing ${ }^{110 \mathrm{~m}} \mathrm{Ag}$ were introduced into the pool, which also contained ${ }^{60} \mathrm{Co},{ }^{58} \mathrm{Co},{ }^{124} \mathrm{Sb},{ }^{51} \mathrm{Cr},{ }^{3} \mathrm{H}$, and ${ }^{14} \mathrm{C}$. Purification by resins was stopped on day 30 . From day 35 to day 56 , the water was purified by uptake of radionuclides by the suspended algae, which were then collected onto a micropore filter (diameter $50 \mathrm{~mm}$, height $60 \mathrm{~mm}$ ) installed in a mobile pool surface robot. The algae concentration in water on day 35 was roughly estimated to be $10^{4}$ to $10^{5}$ cells per mL. Important uncertainty arises from a non-homogeneous distribution of algae according to the depth of the pool (higher concentration close to the surface). The micro-pore filter is installed in front of a $14 \mathrm{~m}^{3} \mathrm{~h}^{-1}$ pump which forces the circulation of the algae and contaminated water through the filter. The resulting highly radioactive filters containing $60-100 \mathrm{MBq}$ each were changed every 2 days. The total alga dry weight collected on the filters during the experiment was $40 \mathrm{~g}$. From day 60 , the resins and the normal water circulation were put back into operation, while most of the suspended algae had been collected from the water.

For the direct comparison of the decontamination efficiency using algae or resins (Table 2), a nuclear effluent containing the $\gamma$-emitters ${ }^{60} \mathrm{Co}\left(280 \mathrm{~Bq} \mathrm{~L}{ }^{-1}\right),{ }^{58} \mathrm{Co}\left(140 \mathrm{~Bq} \mathrm{~L}{ }^{-1}\right),{ }^{110 \mathrm{~m}} \mathrm{Ag}(32 \mathrm{~Bq}$ $\left.\mathrm{L}^{-1}\right),{ }^{51} \mathrm{Cr}\left(840 \mathrm{~Bq} \mathrm{~L}^{-1}\right),{ }^{65} \mathrm{Zn}\left(100 \mathrm{~Bq} \mathrm{~L}^{-1}\right)$, and ${ }^{54} \mathrm{Mn}\left(150 \mathrm{~Bq} \mathrm{~L}^{-1}\right)$ and the $\beta$-emitters ${ }^{3} \mathrm{H}\left(260000 \mathrm{~Bq} \mathrm{~L}^{-1}\right)$ and ${ }^{14} \mathrm{C}\left(6000 \mathrm{~Bq} \mathrm{~L}^{-1}\right)$ was contacted with the suspended algae $(160 \mathrm{mg}$ FW per $100 \mathrm{~mL}$ effluent) or with the suspended resins classically used in the nuclear effluent purification process $(80 \mathrm{mg}$ of Purolit NRW100 and $80 \mathrm{mg}$ of Purolit NRW505 (Purolite, Paris, France) ion exchange resins per $100 \mathrm{~mL}$ effluent), under agitation, in the light. After 1 and $24 \mathrm{~h}$, the decontamination rate was determined for each isotope by analyzing its content in water and algae or resin using $\gamma$-spectroscopy or liquid scintillation counting after phase separation by centrifugation at $2000 \mathrm{~g}$.

\section{Results and discussion}

\section{Coccomyxa actinabiotis, a new microalga species isolated from a nuclear facility}

Few autotrophic eukaryotes are capable of living in radioactive nuclear sites. Most organisms previously found in such environments are bacteria such as Kineococcus radiotolerans ${ }^{32}$ or D. radiodurans-related strains ${ }^{33}$ and fungi such as A. alternata, which was isolated from the Chernobyl site after the nuclear disaster. ${ }^{17}$ Extreme environments constitute indeed a unique opportunity for new knowledge in the development of life as well as for novel biotechnologies. We have isolated from the UNFE storage pool of a nuclear site a new autotrophic microalga that is highly resistant to ionizing radiation. The slightly acidic ( $\mathrm{pH}, 5.3 \pm 0.2$ ), demineralized (conductivity, $1.2 \pm 0.2 \mu \mathrm{S} \mathrm{cm}^{-1}$ ), oligotrophic (10 $\mathrm{mg} \mathrm{L}^{-1}$ nitrate; $<0.2 \mathrm{mg} \mathrm{L}^{-1}$ phosphate) pool water contains radionuclides originating from the dissolution and activation of UNFE materials. It is in contact with air, continuously illuminated (200 $\mu \mathrm{mol}$ photons $\mathrm{m}^{-2} \mathrm{~s}^{-1}$ ), and maintained at $25 \pm 3{ }^{\circ} \mathrm{C}$. The UNFEs generate radiologic dose rates varying between $70 \mu \mathrm{Gy} \mathrm{h}^{-1}$ close to the pool walls and the surface and several hundred $\mathrm{Gy} \mathrm{h}^{-1}$ close to the elements.

The alga was harvested and cultured on solid agar plates containing Bold Basal Medium (BBM), a mineral culture medium classically used for algae. ${ }^{34}$ After successive plating of individual alga and isolation of colonies, an axenic strain obtained from one alga cell was isolated, grown in liquid BBM under non-radioactive conditions, and identified at the morphological, biochemical, and genomic level. It is a unicellular freshwater eukaryotic green microalga measuring $6.8 \pm 0.9$ $\mu \mathrm{m} \times 3.8 \pm 0.6 \mu \mathrm{m}$, containing a parietal chloroplast with starch (Fig. 1a and b). The main pigments determined by HPLC are chlorophylls a and b, $\beta$-carotene, and lutein. It multiplies by division with an immobile vegetative stage, by flagellate zooid production, and by auto-spore production. The cell density doubles in 8 days when algae are grown in flasks filled with pool water, compared to about 2 days in BBM. It also grows from its internal reserves in ultra-pure water (conductivity, 0.05 ' $\mu \mathrm{S}$ $\mathrm{cm}^{-1}$ ) for more than one month. Cells gather in colonies in a mucilaginous jelly in the pool but are isolated in culture.

The sequence of the nuclear genome region spanning the ribosomal RNA gene was determined. Pair-wise 18S rDNA sequence alignment yields Coccomyxa chodatii strain SAG 216-2, Coccomyxa peltigerae strain SAG 216-5, Coccomyxa sp. Flensburg fjord 2 (EU127471), Coccomyxa glaronensis strain CCALA 306 (AM167525), and Coccomyxa sp. strain CPCC 508 (AM981206) as the closest species with 98\%, 97\%, 97\%, 96\%, and 96\% sequence identity, respectively. From the phylogenetic cladogram (Fig. 1c), it is inferred that this microalga belongs to the Coccomyxa genus, ${ }^{35}$ which comprises to date more than 30 freshwater and marine species, ${ }^{36}$ including free-living, epiphytic, symbiotic with lichens, trees, or protozoans, and parasitic species..$^{35,37-41}$ However, it exhibits two unique insertions of 545 and $436 \mathrm{bp}$ in the 18S rDNA sequence and distinct ITS sequences. Both its genomic and morphological characteristics make it a new species belonging to the Coccomyxa genus in the Trebouxiophyceae class $^{\mathbf{4 2}}$ (Fig. 1c), which was named C. actinabiotis (CCAP 216-25) meaning "lives in rays".

\section{C. actinabiotis radioresistance}

As $C$. actinabiotis lives in a continuous ionizing radiation environment, its radioresistance properties were quantified and compared to that of $C$. chodatii, one of the taxonomically closest species (Fig. 1c), and of the reference unicellular microalga Chlamydomonas reinhardtii. Cells subjected to acute $\gamma$-irradiation at an intense flux of $4000 \mathrm{~Gy} \mathrm{~h}^{-1}$ integrated doses of up to 
20000 Gy (2 Mrad). Maximum mortality value versus dose, determined using vital staining, reveals that $C$. actinabiotis exhibits an extreme radiation resistance (Fig. 2). Its $\mathrm{LD}_{50}$ is $10000 \mathrm{~Gy}$ and it survives $20000 \mathrm{~Gy}$. Irradiation of up to $6000 \mathrm{~Gy}$ did not affect C. actinabiotis growth (Fig. 3). A 10000 Gy dose induced a growth lag of 2-4 days. Cells irradiated at 20000 Gy recovered the maximum population density of the control in less than 2 weeks. The $\mathrm{LD}_{50}$ was 1500 Gy for $C$. chodatii (Fig. 2), and less than $500 \mathrm{~Gy}$ for $C$. reinhardtii. As mentioned above, few organisms are capable of surviving high ionizing radiation fluxes. They are mainly prokaryotes ${ }^{\mathbf{1 3 - 1 5 , 1 9 , 2 0}}$ but they also include some eukaryotes. ${ }^{16,17,24}$ The lethal dose corresponding to 50\% mortality after $\gamma$-irradiation for other reference or radioresistant species is 250 Gy for the bacterium E. coli ${ }^{19} 2000 \mathrm{~Gy}$ for Dictyostelium discoideum, ${ }^{16} 2500$ Gy for Chroococcidiopsis sp., ${ }^{13} 5700$ Gy and 10700 Gy for D. radiodurans grown respectively on DMM and TGY media. ${ }^{19}$ Although C. actinabiotis is a eukaryote, its survival to ionizing radiation is similar to that of the prokaryote D. radiodurans.

To assess the impact of irradiation on cellular functioning, the metabolic changes that take place in the cell upon irradiation were investigated using NMR. Metabolites, as intermediates or end-products of transcriptomic and/or proteomic changes, represent accurate indicators of the cell biochemical status. ${ }^{44}$ Their qualitative and quantitative determination gives information on the biochemical status of the organism, cellular functioning, and pathways affected by stress or disease. ${ }^{45-47}$ NMR is a powerful technique to obtain cell metabolic profiles which provide such information. ${ }^{48-50}$ The $C$. actinabiotis metabolic content remained highly stable upon irradiation at doses of up to $10000 \mathrm{~Gy}$ (Fig. 4), revealing very efficient protection and/or repair capabilities. It is unlikely that metabolites remain stable because all proteins metabolizing them would be damaged by ionizing radiation. In a less radioresistant alga species actually, a 20000 Gy dose triggers a drastic decrease in most of the metabolites. ${ }^{24}$ In radiosensitive species, lower ionizing radiation doses resulting in cell apoptosis induce a depletion in many metabolites. ${ }^{51,52}$ Moreover, the fact that C. actinabiotis growth is not significantly different after irradiation at doses of up to 6000 Gy means that cells are still alive. Specifically, the sucrose pool was maintained one day after irradiation even in the 10000 Gy irradiated sample (Fig. 5a), indicating that the sugar energy source pathways were still functional or had been rapidly repaired. Cells were still able to provide the substantial energy needed to repair the damage caused by ionizing radiations to macromolecules. Ionizing radiation actually generates damages to macromolecules (DNA and proteins), the number of DNA double-strand breaks (DSBs) being roughly proportional to dose. One gray induces about 0.002-0.005 DSBs per Mbp in many species, whether radioresistant or not. ${ }^{\mathbf{1 9 5 3 , 5 4}}$ Doses of 10000 Gy thus introduce hundreds to a few thousands of DSBs into the $C$. actinabiotis genome. From the metabolic perspective, a 10000 Gy dose triggered a statistically significant increase in the pools of some main amino acids such as valine and isoleucine (Fig. 5a), also observed in other species submitted to sublethal UV- or

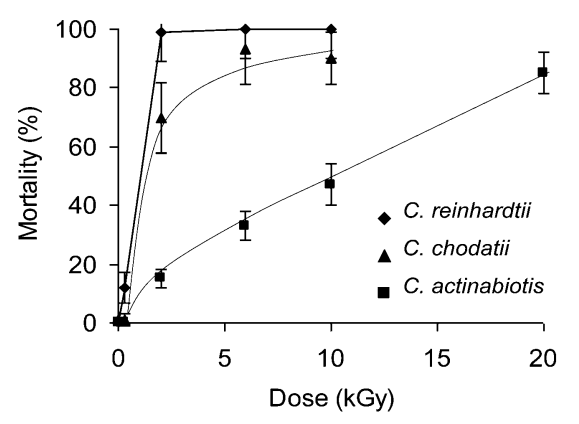

Fig. 2 Resistance to ionizing radiation of C. actinabiotis compared to other microalga strains. Acute $\gamma$-irradiation was performed at a dose rate of $4000 \mathrm{~Gy}$ $\mathrm{h}^{-1}$. Mortality values obtained three days after irradiation are average \pm standard deviation ( $n=3$ except $n=2$ at $20000 \mathrm{~Gy}$ ).
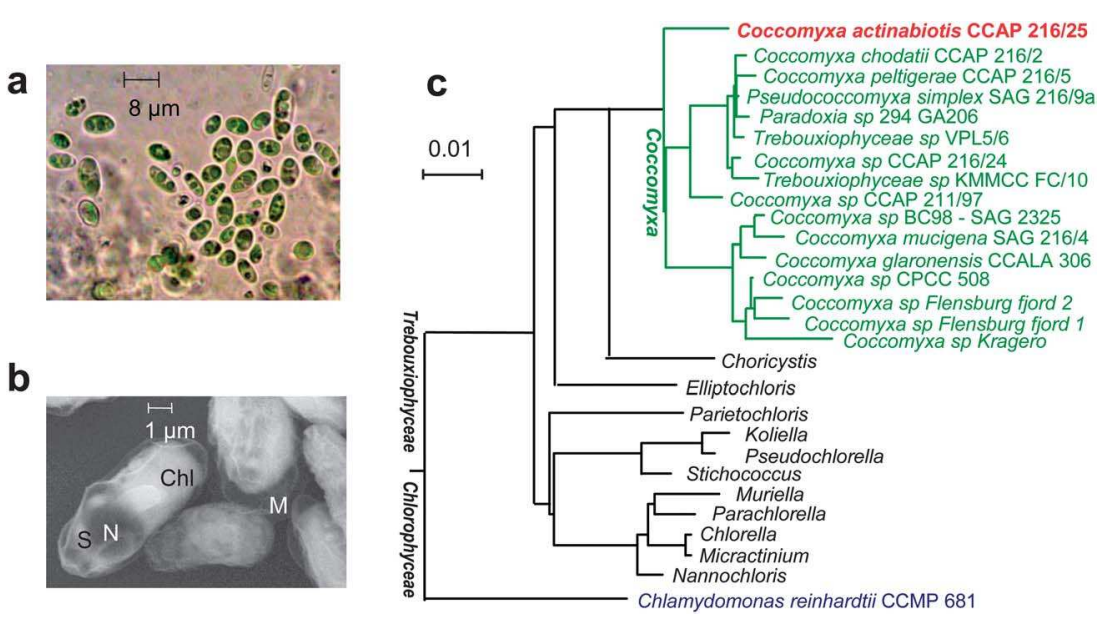

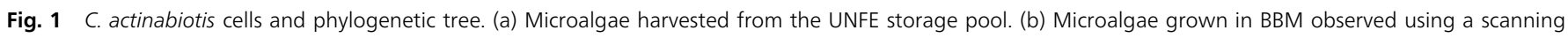

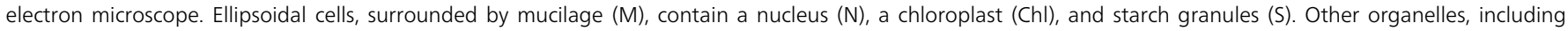

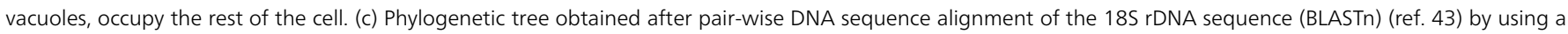
maximum likelihood approach. The upper scale indicates a $1 \%$ substitution ratio. 


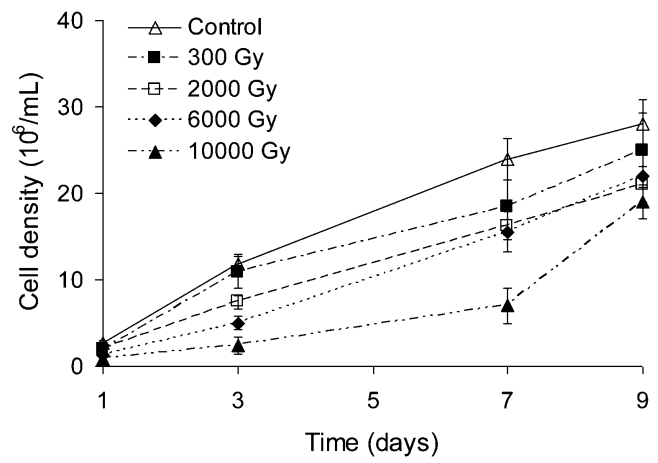

Fig. 3 Growth of C. actinabiotis after acute $\gamma$-irradiation at 300, 2000, 6000, and $10000 \mathrm{~Gy}$. Values are average of triplicate experiments \pm standard deviation.

$\gamma$-irradiation doses, ${ }^{24,46,51}$ which suggests a partial protein lysis or synthesis activity related to irradiation. ${ }^{24,46,51}$ However, 9 days after irradiation, the algae metabolite content did not significantly differ whatever the irradiation dose (Fig. 5b), suggesting the complete recovery of cellular functioning.

How can a living organism withstand such doses that damage glass and plastic, turning them brittle? In $D$. radiodurans, the origin of this amazing survival still remains unclear; numerous studies point to a set of resistance and repair mechanisms ${ }^{19,20,55-57}$ including multiple genome copies, extremely efficient functioning of conventional DNA repair systems, and protein protection against oxidative damage generated by irradiation via high $\mathrm{Mn} / \mathrm{Fe}$ ratios. Mechanisms that protect or repair C. actinabiotis are presently unknown. Preliminary experiments using gel electrophoresis suggest that C. actinabiotis could be able to restore its genome. C. chodatii also grows after irradiation of $10000 \mathrm{~Gy}$, whereas Chlamydomonas does not; however, C. chodatii withstands lower radiation levels than C. actinabiotis (Fig. 2), indicating that $C$. actinabiotis most probably utilizes specific resistance and repair mechanisms.

\section{Radionuclide and toxic metal accumulation}

To demonstrate whether it is possible to take advantage of the exceptional radioresistance of $C$. actinabiotis to decontaminate radionuclides, the algae were incubated with synthetic and real effluents containing the main radionuclides present in nuclear effluents, namely the $\gamma$-emitters ${ }^{60} \mathrm{Co},{ }^{58} \mathrm{Co},{ }^{110 \mathrm{~m}} \mathrm{Ag},{ }^{124} \mathrm{Sb},{ }^{51} \mathrm{Cr}$, ${ }^{65} \mathrm{Zn},{ }^{54} \mathrm{Mn},{ }^{137} \mathrm{Cs}$, and ${ }^{238} \mathrm{U}$ and the $\beta$-emitters ${ }^{3} \mathrm{H}$ and ${ }^{14} \mathrm{C} .{ }^{58}$ Algae and plants have been considered for radionuclide decontamination. ${ }^{\mathbf{1 0 , 5 9}}$ Uptake capacities of metals or radionuclides depend among others on the organism, its growth conditions, conditioning and concentration, the radionuclide chemical speciation and concentration, the contact time, the presence of competitors within the matrix., ${ }^{9,31,59-63}$

C. actinabiotis in contact with nuclear effluents strongly accumulates $\gamma$-emitters. Substantial BCFs reached 450000 for ${ }^{110 \mathrm{~m}} \mathrm{Ag}$ and 35000 for ${ }^{60} \mathrm{Co}$ in algae directly harvested from the pool (Fig. 6). Cobalt and silver represent 77 to $94 \%$ of the $\gamma$-emitters released in liquid effluents of pressurized water nuclear reactors. ${ }^{64}$ Silver also belongs to the highest toxic class of heavy metals with cadmium, surpassed only by mercury. ${ }^{65,66}$ Values obtained in this work are among the upper values of the wide range of BCFs reported for these elements in microalgae, namely $1700-400000 \mathrm{~mL} \mathrm{~g}^{-1} \mathrm{FW}$ for silver ${ }^{30,31,67}$ and $300-3300$ $\mathrm{mL} \mathrm{\textrm {g } ^ { - 1 }}$ FW or $40000 \mathrm{~mL} \mathrm{~g}^{-1}$ dry weight (DW) for radiocobalt. ${ }^{30,68,69}$

In $24 \mathrm{~h}$, C. actinabiotis completely removed ${ }^{110 \mathrm{~m}} \mathrm{Ag},{ }^{65} \mathrm{Zn}$, and ${ }^{137} \mathrm{Cs}$ from nuclear effluents and fixed more than $90 \%$ of ${ }^{60} \mathrm{Co}$, ${ }^{58} \mathrm{Co},{ }^{54} \mathrm{Mn}$, and ${ }^{238} \mathrm{U}$ (Table 1). Decontamination of ${ }^{14} \mathrm{C}$ reached $85 \%$. C. actinabiotis shows very efficient radionuclide uptake. In other microalgae including Scenedesmus, Cyclotella, and Chlorella sp., decontamination rates of $45-100 \%, 43-80 \%$, and $45-$ $95 \%$ have been reported for ${ }^{110 \mathrm{~m}} \mathrm{Ag}, \mathrm{Co}$, and $\mathrm{U}$, respectively. ${ }^{30,31,59,70-72}$

Concerning the overall resistance of C. actinabiotis to metallic toxicity, high fixation capacities were obtained for nonradioactive silver and cobalt, namely 15 and $20 \mathrm{mg}$ silver $\mathrm{g}^{-1} \mathrm{FW}$

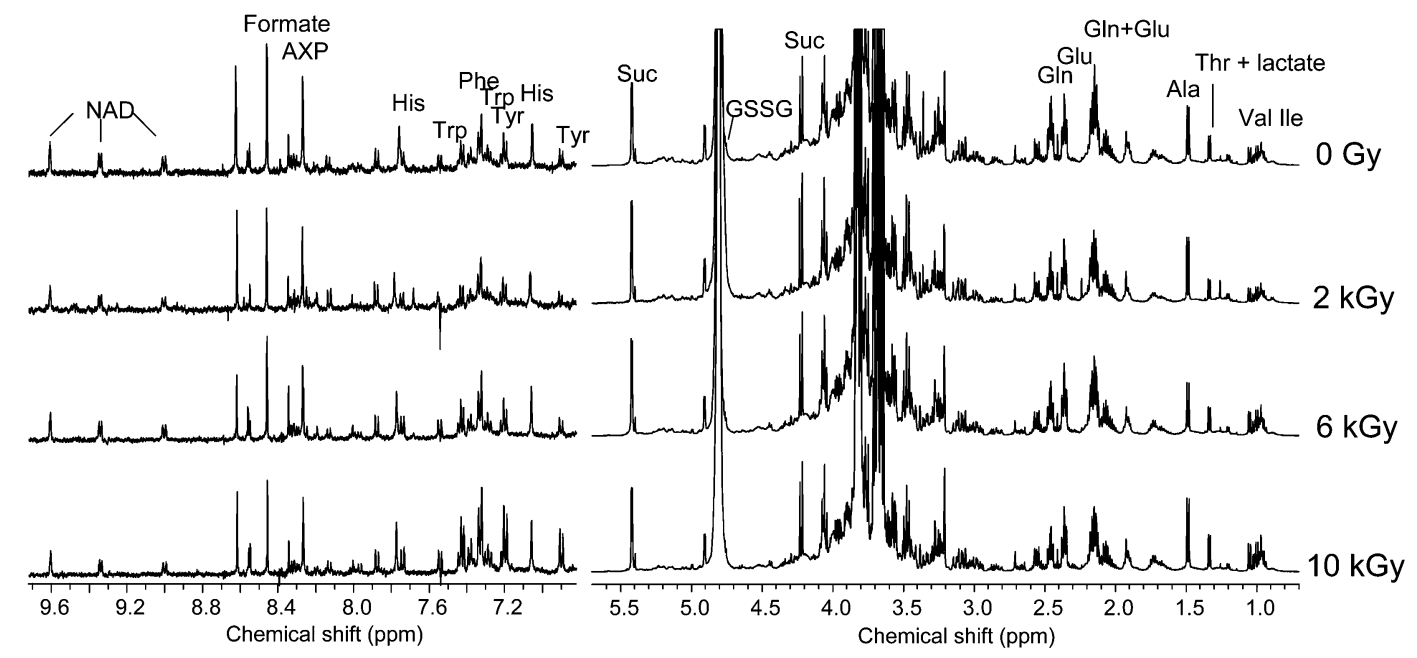

Fig. 4 Algae metabolic profile obtained using ${ }^{1} \mathrm{H}$ NMR one day after an acute irradiation at 2000, 6000, and $10000 \mathrm{~Gy}$, corresponding to an exposure time of 30 min, $1.5 \mathrm{~h}$, and $2.5 \mathrm{~h}$, respectively, compared to control algae. Peak identification: Suc, sucrose, Gln, glutamine, Glu, glutamate, Ala, alanine, Val, valine, His, histidine, Trp, tryptophan, Phe, phenylalanine, lle, isoleucine, Tyr, tyrosine, GSSG, glutathione, AXP, adenosine mono/di/triphosphate, NAD, nicotinamide adenine dinucleotide. 
a
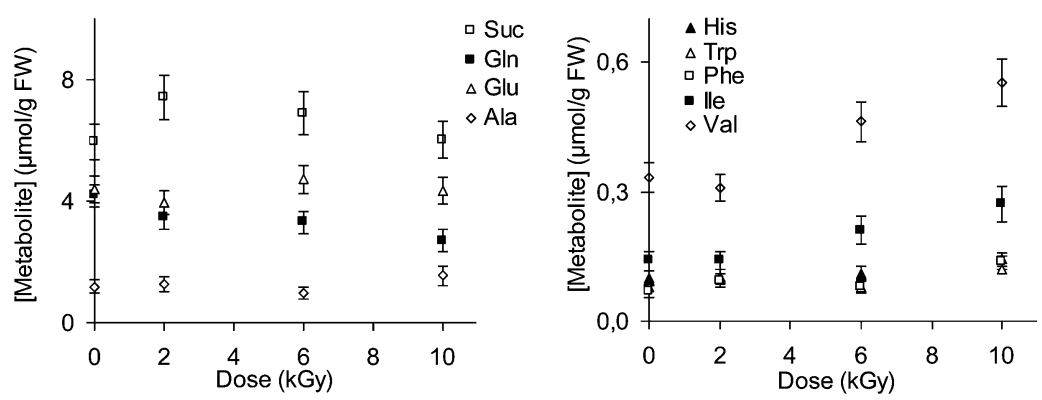

b
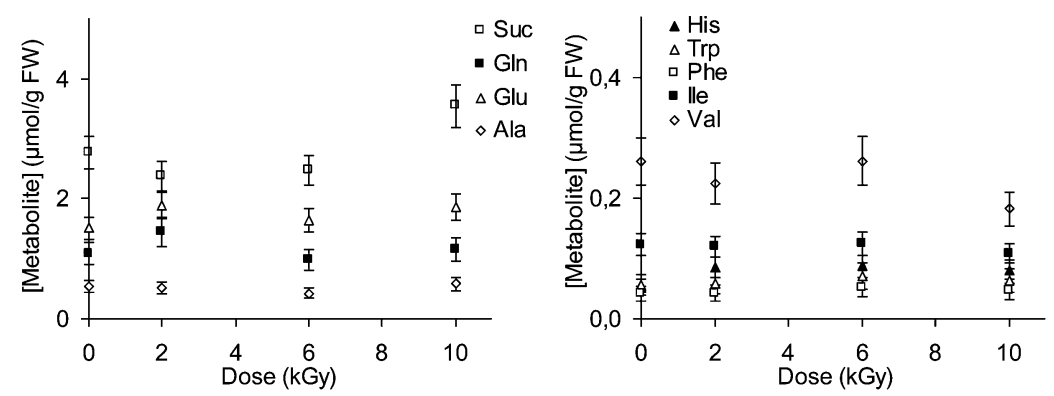

Fig. 5 Changes in the cellular metabolic content in response to irradiation. Metabolite concentration, in $\mu \mathrm{mol} \mathrm{g}^{-1} \mathrm{FW}$, as a function of the radiation dose, in $\mathrm{kGy}$, (a) 1 day and (b) 9 days after acute irradiation. Abbreviations as in Fig. 4.

in algae exposed to $\mathrm{Ag}^{+}$in water and in diluted $\mathrm{BBM}$, respectively, and $1.5 \mathrm{mg}$ cobalt $\mathrm{g}^{-1} \mathrm{FW}$ in algae exposed to $\mathrm{Co}^{2+}$ in diluted BBM, i.e. about $150-200 \mathrm{mg} \mathrm{Ag}$ and $15 \mathrm{mg} \mathrm{Co} \mathrm{g}^{-1} \mathrm{DW}$, at the same level as the reported extremes. ${ }^{65,69,73-75}$ Maximal values of $300 \mathrm{mg}$ silver $\mathrm{g}^{-1} \mathrm{DW}$ were reported in a Pseudomonas containing bacterial community ${ }^{76}$ and up to $6 \mathrm{mg}$ cobalt $\mathrm{g}^{-1} \mathrm{DW}$ in the zinc hyperaccumulator Thlaspi caerulescens. ${ }^{77}$

C. actinabiotis fixes various radionuclides and toxic metals, both concentration factors and fixation capacities revealing a great affinity for silver and cobalt. Algae and plants are able to chelate and immobilize metallic contaminants on their surface, as well as to incorporate and sequester them within their cytosol or vacuoles, changing their speciation into less-toxic forms. ${ }^{11,22}$ Mechanisms for metallic ion fixation in C. actinabiotis might be related to the mucilage shell surrounding the cells (Fig. 1b) and to intracellular concentration.

Biological radionuclide decontamination has mainly been implemented in low dose rate environments. Moreover, most studies have addressed uranium whose main isotope activity is low, typically $1.3 \mathrm{~Bq} \mathrm{~L}^{-1}$ for a $100{ }^{\wedge} \mu \mathrm{g} \mathrm{L} \mathrm{L}^{-1}$ solution of ${ }^{238} \mathrm{U}$. The originality of C. actinabiotis lies in the combination of its extreme resistance to ionizing radiation and its ability to uptake very efficiently toxic metals and radionuclides, enabling its use in highly radioactive environments.

\section{Real-scale radionuclide biodecontamination using $C$. actinabiotis}

Despite significant research efforts on biodecontamination, very few industrial set-ups for radionuclide biodecontamination are operational., ${ }^{9,10}$ Real-scale radionuclide bio-decontamination was then tested in situ in a $360 \mathrm{~m}^{3}$ storage pool of radioactive components using C. actinabiotis in suspension in water and compared to conventional methods. The storage pool water is usually purified by ion-exchange resins that fix radionuclides. An extremely active nuclear component releasing ${ }^{110 \mathrm{~m}} \mathrm{Ag}$ was introduced in the pool on day 14 (Fig. 7), leading to an increase in radioactivity in water despite the resin-based purification. Resin-based purification was stopped on day 30 and the level of radionuclides strongly increased thereafter. The classical purification process was then replaced by algae-based decontamination for 21 days. The decrease in the concentration of the main radionuclide, ${ }^{110 \mathrm{~m}} \mathrm{Ag}$, observed between days 35 and 56 , originates from its uptake by algae in suspension, which were then collected onto filters. Fig. 7 shows that exponential

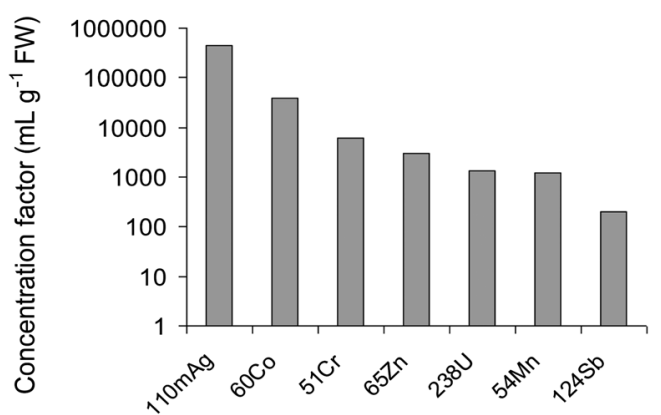

Fig. 6 Bio-concentration factors, in $\mathrm{mL} \mathrm{g}^{-1} \mathrm{FW}$, of the radionuclides ${ }^{110 \mathrm{~m}} \mathrm{Ag}$, ${ }^{60} \mathrm{Co},{ }^{51} \mathrm{Cr},{ }^{65} \mathrm{Zn},{ }^{54} \mathrm{Mn},{ }^{124} \mathrm{Sb}$, and ${ }^{238} \mathrm{U}$ by the microalga $\mathrm{C}$. actinabiotis. 
Table 1 Decontamination of $\gamma$ - and $\beta$-emitter radionuclides, in percentage of the initial radionuclide concentration, in nuclear facility effluents using $C$. actinabiotis

\begin{tabular}{llr}
\hline Radionuclide & Matrix $^{a}$ & Bio-decontamination rate $^{b}(\%)$ \\
\hline${ }^{110 m} \mathrm{Ag}$ & Effluent 1 & $100 \pm 0$ \\
${ }^{60} \mathrm{Co}$ & Effluent 1 & $91 \pm 4$ \\
${ }^{58} \mathrm{Co}$ & Effluent 1 & $91 \pm 4$ \\
${ }^{124} \mathrm{Sb}$ & Effluent 1 & $30 \pm 4$ \\
${ }^{51} \mathrm{Cr}$ & Effluent 1 & $48 \pm 5$ \\
${ }^{65} \mathrm{Zn}$ & Effluent 1 & $100 \pm 0$ \\
${ }^{54} \mathrm{Mn}$ & Effluent 1 & $90 \pm 3$ \\
${ }^{137} \mathrm{Cs}$ & Effluent 2 & $100 \pm 1$ \\
${ }^{238} \mathrm{U}$ & Effluent 2 & $95 \pm 2$ \\
${ }^{14} \mathrm{C}$ & Matrix 3 & $85 \pm 5$
\end{tabular}

${ }^{a}$ Decontamination was measured using different nuclear effluents containing various radionuclides. The initial composition of each effluent is described in Materials and methods. ${ }^{b}$ Suspended microalgae were contacted for $24 \mathrm{~h}$ with effluents 1 and 2 and for 3 to $7 \mathrm{~h}$ with matrix 3. The concentration of each isotope was then determined in algae and water using $\gamma$-spectroscopy or liquid scintillation counting. Values are average of triplicate experiments \pm standard deviation.

decrease in the activity profile and hence in the purification efficiency by microalgae is comparable to that by resins. On the whole, the algae removed $740 \pm 7 \mathrm{MBq} \gamma$-emitters, including $310 \pm 5 \mathrm{MBq}{ }^{110 \mathrm{~m}} \mathrm{Ag}, 270 \pm 5 \mathrm{MBq}{ }^{51} \mathrm{Cr}$, and $30 \pm 5 \mathrm{MBq}{ }^{60} \mathrm{Co}$ from the pool in 21 days. The mean activity collected by C. actinabiotis was $20 \pm 5 \mathrm{MBq} \mathrm{g}^{-1} \mathrm{DW}$. A challenge in the nuclear industry is the reduction of the ultimate radioactive waste volume that requires careful and safe storage and disposal. Once dried, the algae volume was reduced by $90 \%$. The volume of radioactive waste generated was then at least 100 times lower than that of resins.

The decontamination efficiency of algae was also directly compared to that of the resins. When using $160 \mathrm{mg}$ algae FW i.e. $16 \mathrm{mg}$ DW per $100 \mathrm{~mL}$ nuclear effluent (which corresponded to $10^{7}$ cells per $\mathrm{mL}$ ), the decontamination efficiency was similar to that obtained with $80 \mathrm{mg}$ resin per $100 \mathrm{~mL}$ effluent for the $\gamma$-emitter radionuclides ${ }^{110 \mathrm{~m}} \mathrm{Ag},{ }^{58} \mathrm{Co},{ }^{60} \mathrm{Co}$, and ${ }^{54} \mathrm{Mn}$ after a $1 \mathrm{~h}$ contact time (Table 2). ${ }^{51} \mathrm{Cr}$ decontamination by resins was higher. Conversely, ${ }^{65} \mathrm{Zn}$ decontamination by

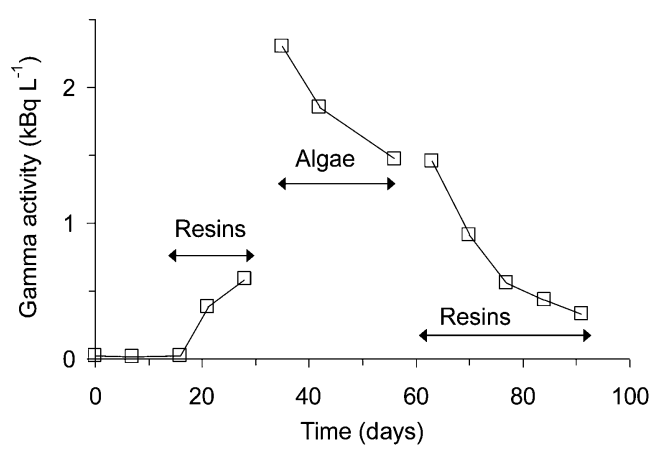

Fig. 7 Decontamination of radionuclides (activity of the main $\gamma$-emitter ${ }^{110 \mathrm{~m}} \mathrm{Ag}$ ) in a storage pool of radioactive components using C. actinabiotis and comparison with the physico-chemical decontamination method using ion-exchange resins.
Table 2 Comparison of the decontamination efficiency of nuclear effluents, in percentage of the initial radionuclide concentration, using the biological (algaebased) and the physico-chemical (resin-based) methods

\begin{tabular}{|c|c|c|c|c|c|}
\hline \multirow[b]{3}{*}{ Radionuclide } & \multicolumn{5}{|c|}{ Decontamination rate ${ }^{a}$} \\
\hline & \multirow{2}{*}{$\frac{\text { Contact time }}{\text { Method }}$} & \multicolumn{2}{|l|}{$1 \mathrm{~h}$} & \multicolumn{2}{|l|}{$24 \mathrm{~h}$} \\
\hline & & Algae & Resins & Algae & Resins \\
\hline${ }^{51} \mathrm{Cr}$ & & $28 \pm 2$ & $47 \pm 2$ & $94 \pm 2$ & $100 \pm 1$ \\
\hline${ }^{54} \mathrm{Mn}$ & & $59 \pm 3$ & $56 \pm 3$ & $86 \pm 2$ & $100 \pm 1$ \\
\hline${ }^{58} \mathrm{Co}$ & & $57 \pm 3$ & $49 \pm 3$ & $65 \pm 2$ & $100 \pm 1$ \\
\hline${ }^{60} \mathrm{Co}$ & & $53 \pm 3$ & $54 \pm 3$ & $66 \pm 2$ & $100 \pm 1$ \\
\hline${ }^{65} \mathrm{Zn}$ & & $80 \pm 3$ & $40 \pm 2$ & $79 \pm 3$ & $100 \pm 1$ \\
\hline${ }^{110 \mathrm{~m}} \mathrm{Ag}$ & & $100 \pm 1$ & $100 \pm 1$ & $100 \pm 1$ & $100 \pm 1$ \\
\hline${ }^{14} \mathrm{C}^{11 \mathrm{C}}$ & & $21 \pm 1$ & $13 \pm 2$ & $82 \pm 4$ & $27 \pm 4$ \\
\hline
\end{tabular}

${ }^{a}$ Nuclear effluents containing radionuclides were contacted with either algae $\left(160 \mathrm{mg} \mathrm{DW} \mathrm{L}^{-1}\right)$ or resins $\left(800 \mathrm{mg} \mathrm{DW} \mathrm{L}^{-1}\right)$. The concentration of each radionuclide was determined in algae or resins and in water using $\gamma$-spectroscopy or liquid scintillation counting. Values are average of triplicate experiments \pm standard deviation.

algae was twice greater, probably because zinc is a physiological metal taken up by the cells via active mechanisms. ${ }^{22}$ Decontamination efficiency using algae increased after $24 \mathrm{~h}$, though less or identical to that obtained using resins, except for ${ }^{14} \mathrm{C}$. The removal of ${ }^{14} \mathrm{C}$ is usually problematic using ionexchange resins and only reached $27 \%$ in this experiment. Whatever the contact time, the decontamination efficiency was far superior using illuminated algae (Table 2) owing to ${ }^{14} \mathrm{C}$ incorporation inside the cells through metabolically mediated processes, particularly through photosynthesis. In this kind of application, living organisms are advantageous for overall maximal decontamination performance. Algae also have the advantage of smaller waste volumes compared to resins. Once dried, the algae retained the totality of the $\gamma$-emitters and $97 \%$ of the ${ }^{14} \mathrm{C}$ fixed during the decontamination step, yielding for this experiment a ultimate waste volume reduction of 5 compared to resins.

\section{Conclusions}

The newly discovered microalga $C$. actinabiotis not only exhibits an exceptional radioresistance but also possesses several other assets. From its photosynthetic activity, it can produce the organic materials it needs for its metabolism and growth. It only needs light, water, $\mathrm{CO}_{2}$, and a few dissolved minerals to grow. It can thrive in a radioactive environment and is also capable of capturing and concentrating, rapidly and efficiently, radionuclides in nuclear facility effluents. The feasibility of the bio-decontamination of radionuclides on a real-scale has been demonstrated. This alga is an excellent candidate for new methods of remediation. The algae-based methods could be used inside nuclear facilities, where they would complement or replace conventional methods and reduce the volume of radioactive waste, at the exit point from nuclear facilities to reduce radioactive emissions into the environment, or for the decontamination of accidentally 
polluted water. An industrial pilot of the bio-process is currently under development at the French Atomic Energy Commission (CEA) and at the Laue Langevin Institut.

\section{Acknowledgements}

We thank J. Tribolet, C. Barbe, S. Million, B. Desbrières, M. Mollier, C. Chevy, and L. Brayer for algae irradiation in the UNFE and for real-scale experiments, C. Brouard for his help in ${ }^{14} \mathrm{C}$ measurements, G. Rignon and O. Duny for gamma-activity measurements, M. Kuntz for HPLC analyses of the alga pigments, S. Bohic for cell cryo-desiccation, I. Snigireva and T. Leonardo for the SEM image, J. Martin-Laffon for her help in bibliographic research, and $\mathrm{S}$. Tinniswood for manuscript reading. This work is supported by the Transversal Nuclear Toxicology program of the CEA and by the ILL.

\section{References}

1 G. Brumfiel, Fukushima set for epic clean-up, Nature, 2011, 472, 146-147, DOI: 10.1038/472146a.

2 Organisation for Economic Co-operation and Development, Chernobyl: Assessment of Radiological and Health Impacts, OECD Papers, Paris, France, 2003, vol. 3, issue 1.

3 Nuclear and Industrial Safety Agency, 2011, http:// www.nisa.meti.go.jp/english/files/en20110325-6.pdf.

4 Radiation effects from Fukushima I nuclear accidents, 2011, http://en.wikipedia.org/wiki/Radiation_effects_from_Fukushima_ I_nuclear_accidents.

5 M. J. Thornley, J. Appl. Bacteriol., 1963, 26, 334-345.

6 V. M. Efremenkov, IAEA Bull., 1989, 4, 37-42.

7 International Atomic Energy Agency, Combined methods for liquid radioactive waste treatment, IAEA-TECDOC-1336, Vienna, Austria, 2003.

8 International Atomic Energy Agency, Application of Ion Exchange Processes for the Treatment of Radioactive Waste and Management of Spent Ion Exchangers, Technical Reports Series 408, Vienna, Austria, 2002.

9 G. M. Gadd, J. Chem. Technol. Biotechnol., 2009, 84, 13-28.

10 S. Dushenkov, Plant Soil, 2003, 249, 167-175.

11 G. M. Gadd, Microbiology, 2010, 156, 609-643.

12 Phytoremediation: Methods and Reviews. Methods in Biotechnology. 23, Series, ed. N. Willey and series ed. J. M. Walker, Humana Press, Totowa, New Jersey, 2007, p. 478.

13 D. Billi, E. I. Friedmann, K. G. Hofer, M. G. Ciaola and R. Ocampo-Friedmann, Appl. Environ. Microbiol., 2000, 66, 1489-1492.

14 J. DiRuggiero, N. Santangelo, Z. Nackerdien, J. Ravel and F. T. Robb, J. Bacteriol., 1997, 179, 4643-4645.

15 M. Kottemann, A. Kish, C. Iloanusi, S. Bjork and J. DiRuggiero, Extremophiles, 2005, 9, 219-227.

16 R. A. Deering, Science, 1968, 162, 1289-1290.

17 N. V. Mironenko, I. A. Alekhina, N. N. Zhdanova and S. A. Bulat, Ecotoxicol. Environ. Saf., 2000, 45, 177-187.

18 K. R. Gwin and J. R. Battista, in Extremophiles. Microbiology and Biotechnology, ed. R. P. Anitori, Caister Academic Press, Norfolk, UK, 2012, p. 299.
19 M. J. Daly, E. K. Gaidamakova, V. Y. Matrosova, A. Vasilenko, M. Zhai, A. Venkateswaran, M. Hess, M. V. Omelchenko, H. M. Kostandarithes, K. S. Makarova, L. P. Wackett, J. K. Fredrickson and D. Ghosal, Science, 2004, 306, 10251028.

20 M. J. Daly, Nat. Rev. Microbiol., 2009, 7, 237-245.

21 H. Brim, S. C. McFarlan, J. K. Fredrickson, K. W. Minton, M. Zhai, L. P. Wackett and M. J. Daly, Nat. Biotechnol, 2000, 18, 85-90.

22 S. Clemens, Biochimie, 2006, 88, 1707-1719.

23 International Atomic Energy Agency, Effects of ionizing radiation on aquatic organisms and ecosystems. Technical reports series 172, Vienna, Austria, 1976.

24 E. Farhi, C. Rivasseau, M. Gromova, E. Compagnon, V. Marzloff, J. Ollivier, A. M. Boisson, R. Bligny, F. Natali, D. Russo and A. Couté, J. Phys.: Condens. Matter, 2008, 20, 104216.

25 M. R. Krejci, L. Finney, S. Vogt and D. Joester, ChemSusChem, 2011, 4, 470-473.

26 R. A. Lovett, Algae holds promise for nuclear clean-up, Nature, 2011, DOI: 10.1038/news.2011.195.

27 J. W. Daniell, W. E. Chappell and H. B. Couch, Plant Physiol., 1969, 44, 1684-1689.

28 B. Naton, K. Hahlbrock and E. Schmelzer, Plant Physiol., 1996, 112, 433-444.

29 M. Gromova and C. Roby, Physiol. Plant., 2010, 140, 111-127.

30 C. Adam and J. Garnier-Laplace, Limnol. Oceanogr., 2003, 48, 2303-2313.

31 J. Garnier and J. P. Baudin, Water, Air, Soil Pollut., 1989, 45, 287-299.

32 R. W. Phillips, J. Wiegel, C. J. Berry, C. Fliermans, A. D. Peacock, D. C. White and L. J. Shimkets, Int. J. Syst. Evol. Microbiol., 2002, 52, 933-938.

33 J. K. Fredrickson, J. M. Zachara, D. L. Balkwill, D. Kennedy, S. M. W. Li, H. M. Kostandarithes, M. J. Daly, M. F. Romine and F. J. Brockman, Appl. Environ. Microbiol., 2004, 70, 4230-4241.

34 Handbook of Phycological Methods. Culture methods and growth measurements, ed. J. Stein, Cambridge University Press, New York, 1973, p. 448.

35 W. Schmidle, Ber. Dtsch. Bot. Ges., 1901, 19, 10-24.

36 M. D. Guiry and G. M. Guiry, AlgaeBase, National University of Ireland, Galway, 2011, http://www.algaebase.org.

37 G. Lamenti, P. Tiano and L. Tomaselli, J. Appl. Phycol., 2000, 12, 427-433.

38 K. Lohtander, I. Oksanen and J. Rikkinen, Lichenologist, 2003, 35, 325-339.

39 J. Trémouillaux-Guiller, T. Rohr, R. Rohr and V. A. R. Huss, Am. J. Bot., 2002, 89, 727-733.

40 R. Hoshina and N. Imamura, Protist, 2008, 159, 53-63.

41 F. Rodríguez, S. W. Feist, L. Guillou, L. S. Harkestad, K. Bateman, T. Renault and S. Mortensen, Dis. Aquat. Org., 2008, 81, 231-240.

42 S. M. Adl, A. G. Simpson, M. A. Farmer, R. A. Andersen, O. R. Anderson, J. R. Barta, S. S. Bowser, G. Brugerolle, R. A. Fensome, S. Fredericq, T. Y. James, S. Karpov, P. Kugrens, J. Krug, C. E. Lane, L. A. Lewis, J. Lodge, 
D. H. Lynn, D. G. Mann, R. M. McCourt, L. Mendoza, O. Moestrup, S. E. Mozley-Standridge, T. A. Nerad, C. A. Shearer, A. V. Smirnov, F. W. Spiegel and M. F. Taylor, J. Eukaryotic Microbiol., 2005, 52, 399-451.

43 S. F. Altschul, W. Gish, W. Miller, E. W. Myers and D. J. Lipman, J. Mol. Biol., 1990, 215, 403-410.

44 O. Fiehn, Plant Mol. Biol., 2002, 48, 155-171.

45 R. Marangoni, D. Paris, D. Melck, L. Fulgentini, G. Colombetti and A. Motta, Biophys. J., 2011, 100, 215-224. 46 C. Rivasseau, M. Seemann, A. M. Boisson, P. Streb, E. Gout, R. Douce, M. Rohmer and R. Bligny, Plant, Cell Environ., 2009, 32, 82-92.

47 J. L. Griffin and J. P. Shockcor, Nat. Rev. Cancer, 2004, 4, 551561.

48 J. K. Nicholson and J. C. Lindon, Nature, 2008, 455, 10541056.

49 E. Gout, R. Bligny, R. Douce, A. M. Boisson and C. Rivasseau, New Phytol., 2011, 189, 135-147.

50 J. L. Griffin, Curr. Opin. Chem. Biol., 2003, 7, 648-654.

51 R. Lee and P. Britz-McKibbin, Electrophoresis, 2010, 31, 2328-2337.

52 A. D. Patterson, L. I. Henghong, G. S. Eichler, K. W. Krausz, J. N. Weinstein, A. J. J. R. Fornace, F. J. Gonzalez and J. R. Idle, Anal. Chem., 2008, 80, 665-674.

53 E. Gladyshev and M. Meselson, Proc. Natl. Acad. Sci. U. S. A., 2008, 105, 5139-5144.

54 P. L. Olive, Radiat. Res., 1998, 150, S42-S51.

55 J. R. Battista, A. M. Earl and M. J. Park, Trends Microbiol., 1999, 7, 362-365.

56 M. M. Cox and J. R. Battista, Nat. Rev. Microbiol., 2005, 3, 882-892.

57 K. Zahradka, D. Slade, A. Bailone, S. Sommer, D. Averbeck, M. Petranovic, A. B. Lindner and M. Radman, Nature, 2006, 443, 569-573.

58 J. Garnier-Laplace, V. Fournier-Bidoz and J. P. Baudin, Radioprotection, 1997, 32, 49-71.

59 M. Kalin, W. N. Wheeler and G. Meinrath, J. Environ. Radioact., 2005, 78, 151-177.
60 S. Klimmek, H. J. Stan, A. Wilke, G. Bunke and R. Buchholz, Environ. Sci. Technol., 2001, 35, 4283-4288.

61 G. W. Garnham, G. A. Codd and G. M. Gadd, FEMS Microbiol. Lett., 1992, 98, 45-50.

62 G. W. Garnham, G. A. Codd and G. M. Gadd, Appl. Microbiol. Biotechnol., 1992, 37, 270-276.

63 J. Liu, R. J. Reid and F. A. Smith, Physiol. Plant., 1998, 104, 351-356.

64 C. Duffa, M. Masson, G. Gontier, D. Claval and P. Renaud, Radioprotection, 2004, 39, 233-254.

65 H. T. Ratte, Environ. Toxicol. Chem., 1999, 18, 89-108.

66 N. Silvestry-Rodriguez, E. E. Sicairos-Ruelas, C. P. Gerba and K. R. Brigh, Rev. Environ. Contam. Toxicol., 2007, 191, 2345.

67 J. R. Reinfelder and S. I. Chang, Environ. Sci. Technol., 1999, 33, 1860-1863.

68 R. Nucho, A. Rambaud, L. Foulquier and J. P. Baudin, Acta Oecol., Oecol. Appl., 1988, 9, 111-125.

69 C. Bresson, E. Ansoborlo, V. Malard, F. Eyrolle and B. Fievet, in Toxicologie nucléaire, environnementale et humaine, ed. Lavoisier, TEC \& DOC, Paris, France, 2009, ch. 29, pp. 553573.

70 A. Cecal, K. Popa, V. Potoroaca and N. Melniciuc-Puica, J. Radioanal. Nucl. Chem., 2002, 251, 257-261.

71 X. Zhang, S. Luo, Q. Yang, H. Zhang and J. Li, J. Appl. Phycol., 1997, 9, 65-71.

72 M. Vogel, A. Günther, A. Rossberg, B. Li, G. Bernhard and J. Raff, Sci. Total Environ., 2010, 409, 384-395.

73 G. W. Garnham, G. A. Codd and G. M. Gadd, Environ. Sci. Technol., 1992, 26, 1764-1770.

74 B. L. Chen, Q. Huang, X. J. Lin, Q. Q. Shi and S. G. Wu, J. Appl. Phycol., 1998, 10, 371-376.

75 C. J. Terhaar, W. S. Ewell, S. P. Dziuba, W. W. White and P. J. Murphy, Water Res., 1977, 11, 101-110.

76 R. C. Charley and A. T. Bull, Arch. Microbiol., 1979, 123, 239244.

77 A. J. M. Baker, R. D. Reeves and A. S. M. Hajar, New Phytol., 1994, 127, 61-68. 